\title{
Factors related to the presence of the Austropotamobius pallipes (Lereboullet, 1858) species complex in calcareous mountin rivers in central Spain
}

\author{
J.A. Arce ${ }^{(1)}$, F. Alonso(1)
}

Received January 20, 2011

Revised April 20, 2011

Accepted May 10, 2011

\section{ABSTRACT}

Key-words: $\quad$ Alto Tajo Natural Park is a protected area in Central Spain. Mainly wellAustropotamobius drained limestone country, this area has traditionally held abundant whitepallipes, distribution, habitat, management clawed crayfish populations. Nevertheless, its occurrence has decreased during the last few decades because of different factors. To address the scarce information on the species, an extensive survey including habitat characterisation was carried out during the summer of 2008, sampling 116 water bodies. Using a combination of survey techniques, a total of 23 populations in different degrees of conservation was found. Crayfish mainly inhabited headwater stretches less than $1 \mathrm{~km}$ in length, together with small ponds. A significant proportion of these populations could be related to previous stocking events. The present study revealed a high degree of isolation, with populations showing a fragmented distribution pattern. The information obtained might be used to discriminate the most adequate localities for future stocking actions, hopefully improving the success of this management tool.

\section{RÉSUMÉ}

Des facteurs liés à la présence du complexe spécifique Austropotamobius pallipes (Lereboullet, 1858) en rivières calcaires de montagne du centre de l'Espagne

Mots-clés : Le parc naturel Alto Tajo est un site protégé situé au centre de l'Espagne. Au caAustropotamobius ractère notamment calcaire, cette zone a hébergé traditionnellement d'abondantes pallipes, distribution, habitat, gestion populations d'écrevisses ibériques. Pourtant, sa présence a été réduite pendant les dernières décades à cause de différents facteurs. Pour pallier ce manque d'information sur les espèces, on a réalisé une étude exhaustive de 116 masses d'eau pendant l'été 2008, y compris une caractérisation d'habitat. En utilisant une combinaison de méthodes de suivi, on a trouvé 23 populations en différents états de conservation. Les écrevisses occupant les têtes de bassin versant sur des tronçons de moins de $1 \mathrm{~km}$ ainsi que de petits étangs. Une proportion significative de ces populations serait issue de précédents repeuplements. Cette étude a prouvé un haut niveau d'isolement des populations qui montrent un modèle de distribution fragmentée. Ces résultats serviront à discriminer les points les plus appropriés pour les futurs repeuplements envisageant une amélioration de l'efficacité de cet outil de gestion.

(1) Centro de Investigación Agraria Albaladejito, Ctra Toledo-Cuenca, Km 176, 16194 Cuenca, Spain, cangrejus24@mixmail.com 


\section{INTRODUCTION}

The white-clawed crayfish, Austropotamobius pallipes (Lereboullet, 1858), species complex was, until recently, an abundant species in Spain. It was present in all the main hydrographic basins (Alonso et al., 2000), chiefly distributed over the limestone country which dominates Eastern Spain. It was less abundant in or absent from the acidic watersheds, which could not provide enough calcium for a proper moulting process (Jussila et al., 1995), and also from arid areas and the highest mountain ranges. Until the end of the 20th century, the A. pallipes species complex provided an important source of both income and sport for local people, as shown by catch data and license numbers (Torre and Rodríguez, 1964; Alonso et al., 2000). Since then, increasing habitat degradation caused by physical disturbance, drainage and sewage has led to its decline, speeded up later by the spread of non-indigenous species transmitting aphanomycosis (Diéguez-Uribeondo et al., 1997; Diéguez-Uribeondo, 2006; Haffner et al., 2006). This decline forced the need for crayfish legal protection, which started with the ban of species fishing in the mid-1980's. It was listed as endangered at a national level in 2004.

Today, around 1200 populations survive (Alonso, pers. com.), mainly located in small headwater creeks and ponds. Most of them are small, and kept isolated from the fluvial network by dry stretches, dams or waterfalls (Martínez et al., 2003). Despite being low, this number represents a substantial increase from previous data (around 600 populations in 2004), mainly due to reintroduction actions and improved distribution knowledge. The Southern Iberian Range represents one of its strongholds, involving over one hundred populations. A previous survey in the neighbouring province of Cuenca detected thirty-eight populations (Martínez et al., 2003).

The Tajo headwaters are included within one of the largest Spanish protected areas. Although known to harbour a substantial white-clawed crayfish stock, detailed information on population numbers, distribution, habitat and conservation status is scarce and outdated. With this work we attempted to improve it, expecting to increase the success of the conservation measures taken.

\section{MATERIALS AND METHODS}

\section{$>$ STUDY AREA}

Alto Tajo Natural Park is a 176000 ha protected area in central Spain (Figure 1). It has a highly continental Mediterranean climate, with extreme summer and winter temperatures. Rainfall is concentrated in spring and, in lesser amounts, in autumn. Located in the Southern Iberian Range, a predominantly limestone system strewn with slate, quartzite and sandstone outcrops, it includes the Tajo basin headwaters. Historically this area and its surroundings held a substantial number of crayfish populations (Torre and Rodríguez, 1964).

\section{$>$ FIELD WORK}

Field work was carried out during the summer of 2008. Sampling sites were selected, taking into account singularity and ease of access criteria, as well as information from river-keepers and previous presence data. All main lotic and lentic water bodies in the Natural Park and its surroundings were covered.

We also sampled sites in which an accumulated 241 documented restocking or reintroduction actions had taken place between 1993 and 2007. Restocking was always carried out in early autumn, and only $\mathrm{O}^{+}$individuals, reared in a neighbouring crayfish state-owned farm and ranging from 15 to $30 \mathrm{~mm}$ in total length, were used (Alonso et al., 2006). The number of juveniles used depended mainly on availability and was highly variable, ranging from 100 to 8000 individuals. 


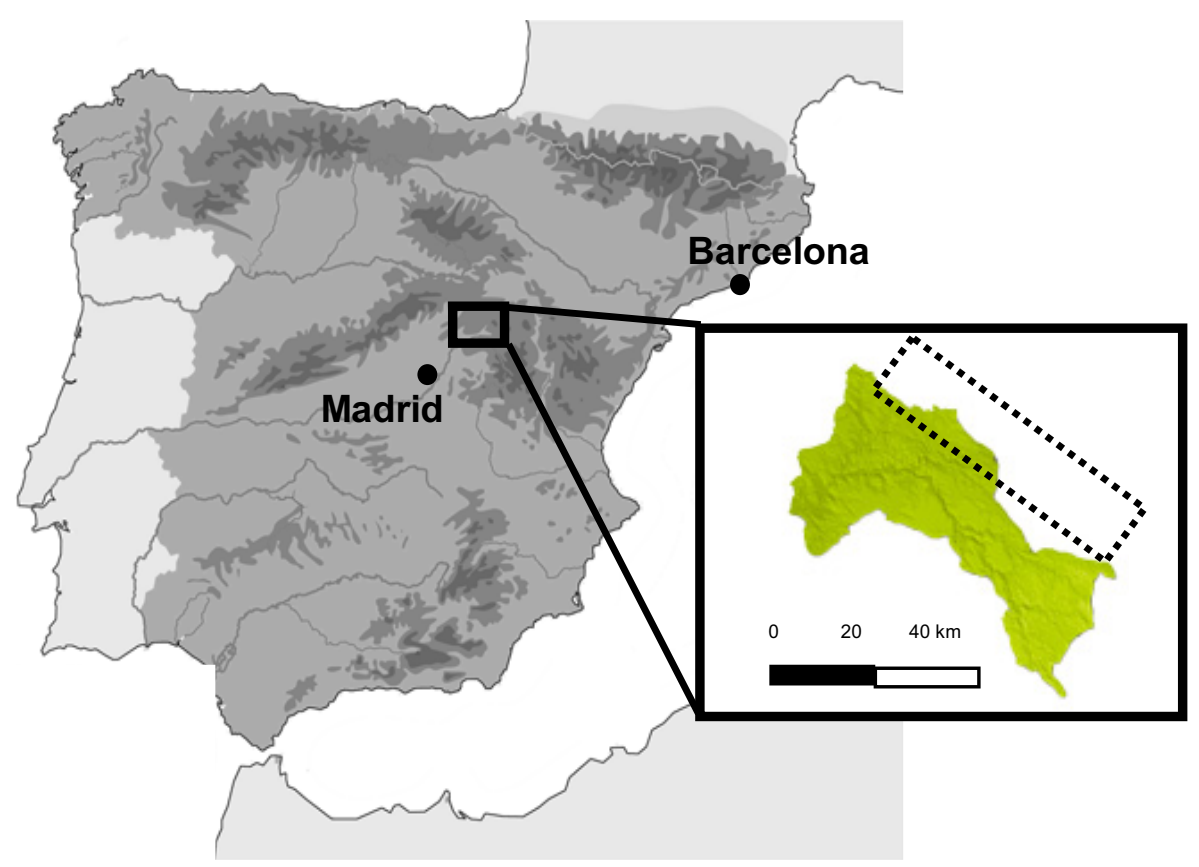

\section{Figure 1}

Situation of Alto Tajo Natural Park in the Iberian Peninsula. The adjacent buffer area also surveyed is represented by a dotted line.

\section{Figure 1 \\ Localisation du parc naturel Alto Tajo dans la Péninsule ibérique. La zone tampon adjacente également échantillonnée est représentée en ligne pointillée.}

The heterogeneity of sampling sites did not allow the application of a single standard survey method (Peay, 2002). Depending on depth, current velocity and water transparency, among others, different techniques, which allowed finding both crayfish and presence signs, such as moults and predation evidence, were used. The primary survey method was active diurnal searches for crayfish, either walking alongside the river banks or wading in the stream and exploring potential shelters. Nocturnal surveys using a torch were sometimes performed, taking advantage of more intense crayfish activity (Gil, 1999). Ponds, big pools and highly turbid or difficult-access reaches were sampled by trapping. A variable number of plastic funnel traps baited with pork liver were set overnight. Sometimes two or three of the above sampling methods were combined. As some methods did not necessarily imply capture of individuals, detected crayfish were only counted and classed by size, being released in any case. The presence/absence of young-of-the-year individuals was also recorded as a reproduction descriptor. In those sites showing negative results, otter spraints were collected when present, since a straightforward visual analysis can identify the presence of crustacean hard external parts in them (Mason and Macdonald, 1986; Kruuk, 2006), allowing in most cases identification to genus level (Arce, 2009). All the material was disinfected between surveys by immersion in a bleach solution.

A simplified habitat characterisation based on the one described by Martínez et al. (2003) was carried out. Temperature, $\mathrm{pH}$, conductivity $(K)$, salinity and total dissolved solids (TDS) were measured in situ employing a multiparametric probe. Nitrate concentration was assessed with a specific nitrate meter. Width and depth were measured to the nearest centimetre with a tape and a graduated stick, respectively, and a GPS was used for altitude records. The substrate, shelter and bank shape were also described. We used a simplified classification for substrate, as shown in Table I. Canopy and macrophyte cover, riffle surface and substrate size proportions were expressed by means of visually estimated percentage classes. Twenty percent amplitude classes were used for canopy and macrophytes, whereas riffle surface 


\section{Table I}

Main habitat features describing sites where Austropotamobius pallipes was present $(+)(n=23)$ or absent $(-)(n=59)$ in Alto Tajo Natural Park. Mean \pm standard deviation, minimum and maximum values are shown for each group.

\section{Tableau I}

Caractéristiques principales de l'habitat décrivant les sites où Austropotamobius pallipes est présente $(+)(n=23)$ ou absente $(-)(n=59)$ dans le parc naturel Alto Tajo. Moyenne \pm déviation standard, valeurs minimum et maximum sont indiquées pour chaque groupe.

\begin{tabular}{|c|c|c|}
\hline \multirow[t]{2}{*}{ Variable } & \multicolumn{2}{|c|}{$\begin{array}{c}\text { Mean } \pm \text { Std. dev. } \\
\text { (range) }\end{array}$} \\
\hline & With A. pallipes & Without $A$. pallipes \\
\hline Population extension (m) & $\begin{array}{c}617.5 \pm 422.6 \\
(10-1400)\end{array}$ & - \\
\hline Altitude ( $m$ above sea level) & $\begin{array}{c}1221.8 \pm 164.2 \\
(961-1547)\end{array}$ & $\begin{array}{c}1058.5 \pm 148.5 \\
(766-1540)\end{array}$ \\
\hline Mean width (m) & $\begin{array}{c}2.54 \pm 2.84 \\
(0.4-10)\end{array}$ & $\begin{array}{c}5.94 \pm 5.36 \\
(0.8-25) \\
\end{array}$ \\
\hline Mean depth (m) & $\begin{array}{c}0.75 \pm 1.67 \\
(0.1-8)\end{array}$ & $\begin{array}{c}0.43 \pm 0.39 \\
(0.05-3)\end{array}$ \\
\hline QBR index & $\begin{array}{c}59.4 \pm 23.4 \\
(20-95)\end{array}$ & $\begin{array}{c}68.7 \pm 24.3 \\
(10-100)\end{array}$ \\
\hline $\mathrm{T}\left({ }^{\circ} \mathrm{C}\right)$ & $\begin{array}{l}15.9 \pm 3.2 \\
(8.3-21.4)\end{array}$ & $\begin{array}{l}17.3 \pm 2.4 \\
(8.7-23.4)\end{array}$ \\
\hline $\mathrm{pH}$ & $\begin{array}{l}7.48 \pm 0.44 \\
(6.57-8.28)\end{array}$ & $\begin{array}{l}7.51 \pm 0.61 \\
(6.63-9.75)\end{array}$ \\
\hline Conductivity $\left(\mu \mathrm{S} \cdot \mathrm{cm}^{-1}\right)$ & $\begin{array}{c}707.9 \pm 450.2 \\
(190-2020)\end{array}$ & $\begin{array}{c}806.3 \pm 787.7 \\
(161-5688)\end{array}$ \\
\hline Salinity $\left(g \cdot L^{-1}\right)$ & $\begin{array}{l}0.34 \pm 0.23 \\
(0.08-1.03)\end{array}$ & $\begin{array}{l}0.40 \pm 0.43 \\
(0.08-3.08)\end{array}$ \\
\hline TDS (mg. $\left.\mathrm{L}^{-1}\right)$ & $\begin{array}{c}365.7 \pm 251.8 \\
(97-1010)\end{array}$ & $\begin{array}{c}403.8 \pm 393.9 \\
(82-2843)\end{array}$ \\
\hline $\mathrm{NO}_{3}\left(\mathrm{mg} \cdot \mathrm{L}^{-1}\right)$ & $\begin{array}{c}12.37 \pm 13.82 \\
(0-39)\end{array}$ & $\begin{array}{c}5.18 \pm 10.52 \\
(0-55)\end{array}$ \\
\hline \% Riffles & $\begin{array}{c}3.0 \pm 2.9 \\
(0-10) \\
\end{array}$ & $\begin{array}{c}2.6 \pm 2.2 \\
(0-10) \\
\end{array}$ \\
\hline$\%$ Canopy cover & $\begin{array}{c}1.9 \pm 1.6 \\
(0-5)\end{array}$ & $\begin{array}{c}2.3 \pm 1.6 \\
(0-5) \\
\end{array}$ \\
\hline \% Submerged macrophytes & $\begin{array}{c}1.36 \pm 1.43 \\
(0-5)\end{array}$ & $\begin{array}{c}1.24 \pm 1.24 \\
(0-5)\end{array}$ \\
\hline \% Bedrock & $\begin{array}{c}1.17 \pm 2.36 \\
(0-10)\end{array}$ & $\begin{array}{c}0.65 \pm 1.94 \\
(0-10)\end{array}$ \\
\hline$\%$ Boulders (> $64 \mathrm{~mm}$ ) & $\begin{array}{c}1.50 \pm 1.58 \\
(0-10)\end{array}$ & $\begin{array}{c}1.21 \pm 1.07 \\
(0-10)\end{array}$ \\
\hline$\%$ Cobbles/coarse gravels (16-64 mm) & $\begin{array}{c}5.28 \pm 2.22 \\
(0-10)\end{array}$ & $\begin{array}{c}5.52 \pm 2.16 \\
(0-10)\end{array}$ \\
\hline$\%$ Fine gravels/sand $(1 / 8-16 \mathrm{~mm})$ & $\begin{array}{c}1.39 \pm 1.58 \\
(0-10)\end{array}$ & $\begin{array}{c}1.60 \pm 1.36 \\
(0-10)\end{array}$ \\
\hline$\%$ Mud/clay $(<1 / 8 \mathrm{~mm})$ & $\begin{array}{c}0.67 \pm 1.03 \\
(0-10)\end{array}$ & $\begin{array}{c}1.0 \pm 1.55 \\
(0-107)\end{array}$ \\
\hline Shelter diversity & $\begin{array}{c}2.74 \pm 1.42 \\
(0-5)\end{array}$ & $\begin{array}{c}2.46 \pm 1.06 \\
(1-5)\end{array}$ \\
\hline Previous restocking actions & $\begin{array}{c}2.91 \pm 2.07 \\
(0-7)\end{array}$ & $\begin{array}{c}2.0 \pm 2.07 \\
(0-7)\end{array}$ \\
\hline Number of potential threats & $\begin{array}{c}3.39 \pm 1.70 \\
(0-7)\end{array}$ & $\begin{array}{c}2.98 \pm 1.55 \\
(0-7)\end{array}$ \\
\hline
\end{tabular}


and substrate types were split into ten percent classes. The presence of eight different shelter types was assessed: crevices within rocks, boulders and cobbles, hollows in banks, submerged stumps, submerged leaves, macrophytes, tree roots and artificial elements. Data for structural variables were averaged between two observers and coded (Table I). We recorded the presence of barriers to crayfish movement, such as falls, dams or dry stretches. Riparian quality was described by means of the QBR index (Munné et al., 2003). Finally, some variables were used to assess human intervention: number of previous restocking actions, land ownership (private or public) and potential threats (categorised as fires, forestry operations, crops, cattle farming, sewage, buildings, destruction of riparian forest, roads, cross barriers, dredging, water removal and presence of nearby non-indigenous crayfish populations).

\section{> STATISTICAL DESIGN}

Variables expressed by proportions were transformed into semi-quantitative ranks for analysis (Table I), as recommended by Clavero et al. (2009). Width was not considered for ponds, and some instream variables could not be measured in some sites due to high turbidity. All the variables were checked for normality with the Shapiro-Wilk test. Only water temperature satisfied this assumption ( $W=0.976 ; p=0.1269$ ). The rest of the continuous variables were log-transformed, whereas those expressed by proportions were normalised by arcsine transformation. Finally, those variables expressing count data were square-root-transformed, as suggested by Sokal and Rohlf (1995).

Data from water bodies with presence of white-clawed crayfish were compared with those localities with no populations. Sites invaded by signal crayfish were excluded from the analysis as in their current state they are not suitable places for the native species. Temperature, altitude, width and nitrate concentration were compared using the Student $t$ test, while the non-parametric Mann-Whitney $U$ test was run for the rest of the variables, including raw data in the model. To discriminate the variables defining the distribution pattern of $A$. pallipes complex populations, we carried out a principal component analysis (PCA). All the tests were carried out with the STATISTICA $7^{\mathrm{TM}}$ pack.

\section{RESULTS}

A total of 115 localities was initially selected, but 24 sites in small creeks were discarded during field surveys, as they were found to be dry on most occasions. Only 91 sites, always more than $10 \mathrm{~cm}$ deep, were retained for sampling. Fifty-three of them (58.2\%) were located in the main streams, while the others were distributed among tributaries (33\%) and still water bodies (8.8\%). The existence of 23 native crayfish populations was confirmed, representing $25 \%$ of the total surveyed localities. Six of the populations were located outside the Natural Park boundaries, but within the buffer area (Figure 2). Five of them occupied natural or artificial ponds, and none were found in the two main rivers, Tajo and Gallo. The length of reaches occupied by crayfish ranged in most cases from 200 to $1000 \mathrm{~m}$. Detection was achieved equally by the three methods used: daily surveys $(n=8)$, nocturnal surveys $(n=6)$ and baited traps $(n=7)$. Two additional populations were assumed to be present on the evidence provided by otter spraints. These were inaccessible stretches heavily invaded by riparian vegetation, being difficult to wade.

Handled crayfish appeared to be in healthy condition everywhere. No reproduction-related activity was observed, and neither abdominal eggs nor spermatic sacs were found, as could be expected from the season during which the survey was carried out. Young $0^{+}$crayfish were present in nine of the populations (39.1\%). Signal crayfish (Pacifastacus leniusculus) were found at six sites outside the Natural Park, all of them along a 13-km stretch in the Gallo river. Red-swamp crayfish (Procambarus clarkii), although present nearby, were not found at any site within the study area. We did not find any mixed-species populations. 


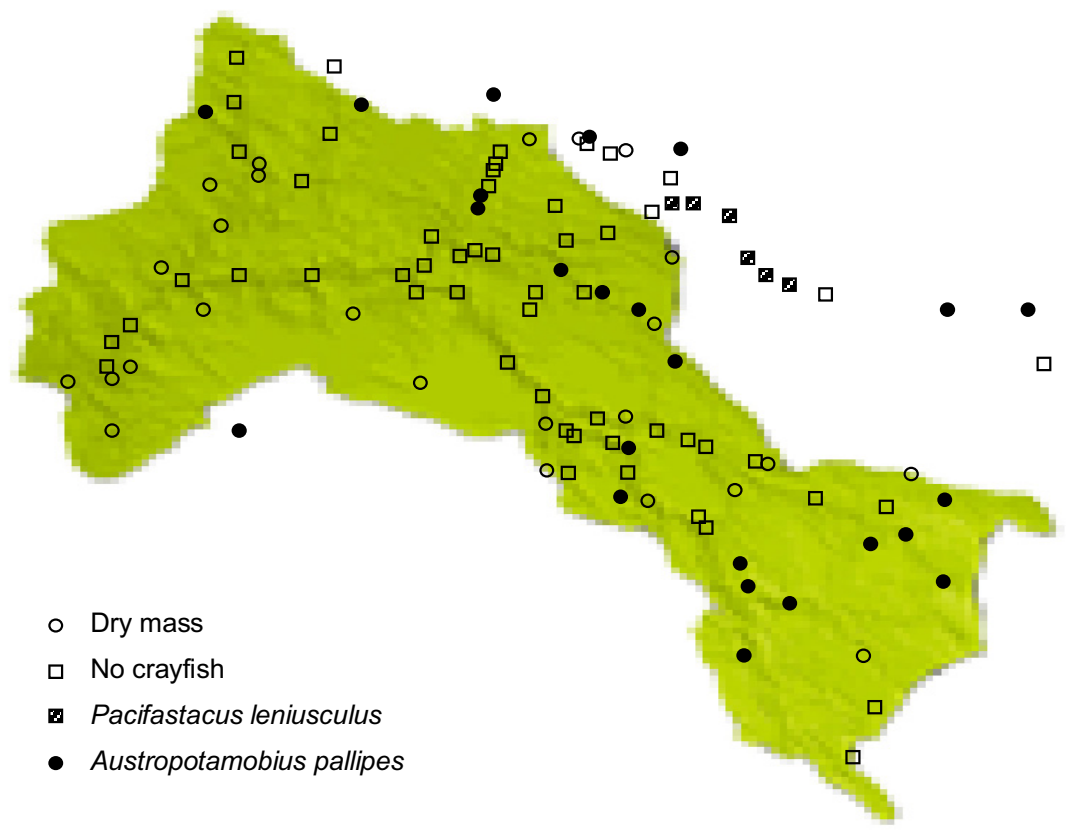

\section{Figure 2}

Distribution of sites sampled in Alto Tajo Natural Park and its buffer area, showing the presence of crayfish species.

\section{Figure 2}

Répartition des sites échantillonnés dans le parc naturel Alto Tajo et sa zone tampon indiquant la présence des écrevisses.

Table I compares the values of main habitat features for native crayfish-inhabited and noninhabited sites. Most were located over $1000 \mathrm{~m}$ a.s.l., and one reached $1547 \mathrm{~m}$ a.s.l. Up to eleven populations (47.2\%) have to withstand severe summer drought conditions, frequently associated with physical barriers (dry stretches, waterfalls) which keep them isolated from the main drainage net. Overall, riverbank vegetation quality was moderate, although some sites reached excellent quality values, as shown by the QBR scores (Table I). Canopy cover was highly variable. Both riffle percentage and macrophyte cover were substantial, averaging around $30 \%$. Only four localities provided macrophyte cover over 50\%, consisting mainly of Groenlandia densa, Apium nodiflorum and Chara sp. Substrate type could not be assessed because of high turbidity in $21.6 \%$ of the sites. In the rest, medium-sized particles were dominant (Table I). More than one type of shelter was present at all crayfish sites, while in more than half of them (56.5\%) three or more different types were available. Three or more distinct threats were identified in $70 \%$ of the populations. Most of them $(91.3 \%)$ had been subjected to at least one restocking/reintroduction event during the last 15 years. Water temperature showed a difference of $13.1^{\circ}$ between the coldest and the warmest sites (Table I). Conductivity was the most variable physicochemical descriptor. Salinity and TDS followed conductivity variations closely $\left(R_{\mathrm{K}-\mathrm{Sal}}=0.9986 ; R_{\mathrm{K}-\mathrm{TDS}}=0.9997\right)$, while $\mathrm{pH}$ indicated the dominance of neutral and alkaline waters. Finally, nitrate concentration was low (Table I).

Only four variables showed significant differences: altitude, width, water temperature and restocking actions. Crayfish occurred at higher sites $\left(p<0.001^{* \star *}, t=4.332\right.$, df $\left.=80\right)$ (Table I). Only two populations were detected below $1000 \mathrm{~m}$ a.s.l. Also, crayfish tended to occur in narrower reaches $\left(p=0.0013^{\star *}, t=3.358\right.$, df $\left.=68\right)$. Water temperature was lower in crayfish sites $\left(p=0.040^{*}, t=2.086, \mathrm{df}=80\right.$ ). Finally, inhabited sites averaged more restocking/reintroduction actions in the recent past than non-inhabited ones, although the significance level was low ( $p=0.048^{\star}, U=490.5$ ). 


\section{Table II}

Summary statistics for the principal component analysis (PCA) defining two main axes for Austropotamobius pallipes in Alto Tajo. Transformed variables from inhabited sites $(n=23)$ were used. In bold, factor loadings $>|0.8|$ for each axis.

\section{Tableau II}

Résultats sur les deux premiers axes d'une analyse en composantes principales (PCA) des données de I'habitat d'Austropotamobius pallipes dans le parc Alto Tajo. Des variables transformées ont été utilisées pour les 23 sites occupés par l'écrevisse. En gras, le poids des facteurs $>|0,8|$ sur chaque axe.

\begin{tabular}{|l|c|c|}
\hline Variables & Factor 1 & Factor 2 \\
\hline Eigenvalue & 9.11 & 4.59 \\
\hline \% Total var. explained & 47.95 & 24.15 \\
\hline Cumulative \% & 47.95 & 72.10 \\
\hline Logalt & $-\mathbf{0 . 8 9 9}$ & -0.077 \\
\hline Depth & $\mathbf{0 . 8 1 7}$ & -0.297 \\
\hline Log width & $\mathbf{0 . 9 2 5}$ & -0.317 \\
\hline QBR & 0.239 & 0.274 \\
\hline \% Bedrock & 0.233 & $\mathbf{0 . 8 4 2}$ \\
\hline \% Boulders & 0.725 & -0.516 \\
\hline \% Cobbles-gravels & $-\mathbf{0 . 8 8 3}$ & -0.119 \\
\hline \% Fine gravels-sand & -0.494 & 0.417 \\
\hline \% Silt-clay & 0.418 & 0.534 \\
\hline \% Riffles & $-\mathbf{0 . 8 8 7}$ & -0.412 \\
\hline \% Canopy cover & -0.441 & -0.277 \\
\hline \% Macrophytes & 0.793 & -0.589 \\
\hline Shelter & $\mathbf{0 . 9 2 8}$ & -0.084 \\
\hline T ${ }^{\circ}$ C) & 0.725 & 0.326 \\
\hline pH & $-\mathbf{0 . 8 0 3}$ & -0.453 \\
\hline $\boldsymbol{K}$ & 0.199 & $-\mathbf{0 . 8 8 1}$ \\
\hline Log NO ${ }_{3}$ & $\mathbf{0 . 9 0 5}$ & -0.274 \\
\hline Restocking actions & 0.338 & 0.761 \\
\hline Potential threats & 0.572 & -0.727 \\
\hline
\end{tabular}

PCA analysis produced two main factors explaining $72.1 \%$ of total variance (Table II). The first axis, responsible for a half of total variance $(47.95 \%)$, was mostly related to water body size. Increasing values yielded lower altitude, wider and deeper sites, lower riffle, cobble and gravel percentages, and lower nitrate levels. The second axis was defined by increasing conductivity and decreasing bedrock proportion.

\section{DISCUSSION}

The combination of several sampling methods allowed us to detect a higher number of populations, and should be considered, not only in terms of efficacy but also of relative effort involved, when sampling wide areas holding diverse crayfish habitat types. Monitoring otter spraints was included as an aid to confirm crayfish presence in some situations. Crayfish can represent an important part of the otter's diet (Mason and Macdonald, 1986; Lanzski and Sallai, 2006) and their hard remains can usually be identified to genus level. The use of otter spraints can be criticised, as they are not released in place just after consumption, so the prey could come from other places. Otters can move several kilometres to explore other areas, but usually behave as territorial mammals (Mason and Macdonald, 1986; Kruuk, 2006). In our study, and in particular in the two native crayfish populations reported by this method, the water bodies are highly isolated between them, making these large movements less probable. Other evidence of predation, although more reliable, is more difficult to find. We found 

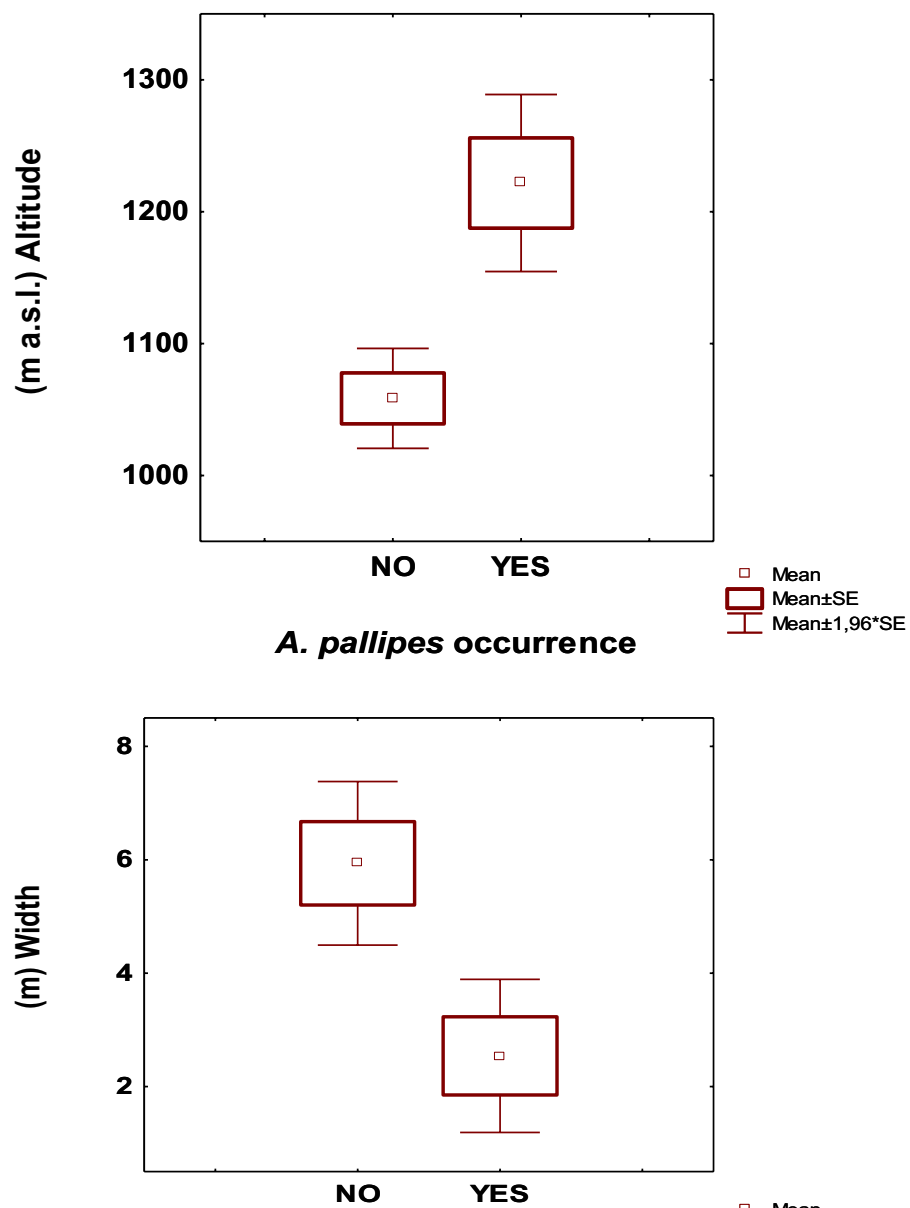

A. pallipes occurrence

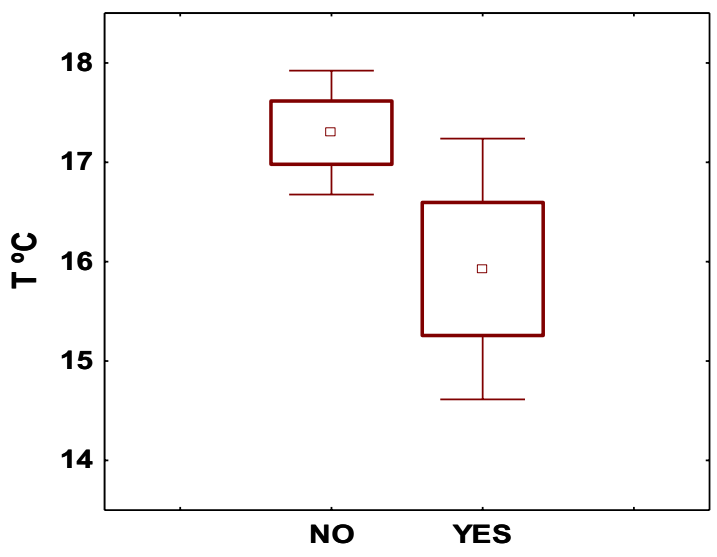

A. pallipes occurrence

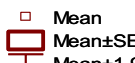

Mean \pm SE

Figure 3

Box-whisker plot comparisons for altitude, water temperature and stretch width between Austropotamobius pallipes inhabited and non-inhabited sites. Mean \pm standard error, and mean $\pm 1.96^{*}$ standard error are shown.

\section{Figure 3}

Graphes en boîtes à moustache comparant l'altitude, la température de l'eau, la largeur du cours d'eau entre les sites occupés ou non par Austropotamobius pallipes. Moyenne \pm erreur standard et moyenne $\pm 1,96^{*}$ erreur standard sont représentées. 
crayfish remains a few times, and only in signal crayfish densely inhabited sites. Both when dealing with dispersed populations at low densities over wide areas, or in places when nonnative crayfish species are actively spreading (Bernardo et al., 2001; Alonso and Martínez, 2006) and an early warning system is needed, this method could provide a complementary affordable alternative within a survey strategy.

Amongst habitat variables, only height, water temperature and stream width showed significant differences between crayfish inhabited and non-inhabited sites. Although height is the factor that explains the distribution of native crayfish in the area better, as in other parts of Spain (Gil and Alba-Tercedor, 2002; Martínez et al., 2006), it probably encompasses the effects of several correlated variables, not only physical, such as water temperature, width, habitat structure and hydrology, but also trophic ones. While in other European countries the A. pallipes complex is also present in lowlands (Troschel and Dehus, 1993; Füreder et al., 2002), its preference for higher reaches seems to be the rule in Spain (Diéguez et al., 1997; Alonso et al., 2000; Gil and Alba-Tercedor, 2002; Martínez et al., 2003). Nonetheless, they select slower flow macrohabitats, such as pools and glides within these higher slope stretches.

Our results support previous observations (Gil and Alba-Tercedor, 2002) on Iberian crayfishes' tolerance to high water temperatures. Non-continuous data probably underestimate this tolerance, especially as small-sized crayfish-inhabited waters can suffer notable oscillations in water temperature under the drastic daily temperature variations of Mediterranean mountain climates. Daily differences of up to $10.5^{\circ} \mathrm{C}$ in water temperature have been recorded in the area (Martínez et al., 2003). Water mineralisation must reach a minimum level for the crayfish to succeed in the moulting process (García-Arberas and Rallo, 2000; Reynolds, 2002). Crayfish use all the wide range of conductivities found in the area, although the best populations are found in waters with medium to high values (over $400 \mu \mathrm{S} \cdot \mathrm{cm}^{-1}$ ), as previously reported (Rallo and García-Arberas, 2000; Martinez et al., 2003).

Riparian vegetation structure was not found to be a limiting factor, as otherwise noted (Benvenuto et al., 2008), and some of our populations lived under low quality riparian vegetation. On the other hand, all populations shared the availability of different types of shelters. Good shelter seems essential to crayfish survival (Guan and Wiles, 1996; Gil and Alba-Tercedor, 2002), its diversity being related to a decrease in predation and agonistic encounters (Gydemo et al., 1990; Blake and Hart, 1993; Garvey et al., 1994; Söderback, 1994; Bergman and Moore, 2003). Gil and Alba-Tercedor (2002) stated that crayfish could even bear adverse levels of certain variables provided enough shelters were available.

Around $20 \%$ of the sites were found to be dry. Together with the high number of populations threatened by prolonged low summer flows, this fact emphasises the pressure that extreme hydrology places on Mediterranean crayfish survival. These isolated stretches with crayfish, frequently of reduced length (Martínez et al., 2003), are even smaller in our study. While providing the isolation that may have led to crayfish survival, keeping them away from aphanomycosis outbreaks, spread of exotic crayfish and other threats, it also makes them much more vulnerable to stochastic events, in particular extreme or maintained droughts, hampering the already low genetic variability observed (Grandjean et al., 2001; Diéguez-Uribeondo et al., 2008), and making spreading downstream difficult. With no mother population remaining in the bigger rivers, the natural upstream colonisation after stochastic extinctions is eliminated. This delicate balance may explain the generalised fragmentation pattern observed in other Iberian areas (Martínez et al., 2003; Alonso, 2010). Even in these adverse circumstances, some populations showed apparently good density and structure. Although not measured in this work, biomass in some well-preserved neighbouring populations in similar habitats yielded values between $7-120 \mathrm{~g} \cdot \mathrm{m}^{-2}$ (Alonso, 2004).

Stocking could be a sensitive way to recover these suitable stretches not accessible to natural colonisation. All but two sites have been restocked or reintroduced once or more in the past. The absence of monitoring programmes does not allow a precise evaluation of the degree of success of each particular action. It makes it difficult even to distinguish between restocking and reintroduction, so we have used the first term in all cases. Martínez et al. (2003) reported in the nearby province of Cuenca that nearly $40 \%$ of the populations were 
found in sites restocked at least once. Similar figures have been observed in other Spanish regions, whether when using $0^{+}$hatchery-reared juveniles or animals of different ages from the wild or previously stocked populations. Recent evaluation of the total number of populations for the whole country showed a substantial increase from ca. 600 in 2004 (Alonso, 2004) to nearly 1200 in 2010 (Alonso, pers. com.), mostly associated with an increase in stocking actions in some provinces. This suggests that, on the whole, stocking could be a very valuable and effective management tool. No significant differences were found in the number of restocking actions in the recent past between sites with or without crayfish, suggesting the need for a sound selection of stocking sites and a monitoring programme to evaluate the success of each particular action.

Among all the threats identified during the study, the signal crayfish population detected in the river Gallo probably represents, in the middle term, the biggest one. More than $300 \mathrm{~km}$ of highly suitable permanent rivers, devoid of any crayfish species and easily accessible through natural colonisation, give the signal crayfish an excellent opportunity to disperse and widely establish in the area, close to most native populations. Some attempts have been started this year to control it, but the river Gallo, while not very wide, is deep and holds heavy macrophyte growth, making it very difficult to achieve even modest results. Human-mediated dispersal should also be taken into account. One of the first Spanish wild signal crayfish populations developed as early as the 1980s close to this area, but no natural or human-led dispersal was observed for twenty years, while fishing for signal crayfish was forbidden all over Spain. But since it was allowed in neighbouring territories a wave of illegal introductions have started, and more than thirty new populations have being detected in the vicinity during the last decade, highlighting the role that expectation of future fishing can play in the dispersal of invasive crayfish (Alonso et al., 2000), which is still going on.

We did not find white-clawed crayfish and signal crayfish living together. These contacts have already been reported elsewhere (Holdich and Domaniewski, 1995; Bubb et al., 2005), and in Spain a mixed population lived in the Ebrón river in the Júcar basin for more than ten years, a situation similar to that described by Holdich and Domaniewski (1995). A new contact has been reported not far from the study area (Antolín, pers. com.). In these cases it seems that native crayfish disappears after several years (Bubb et al., 2005). On the other hand, mixed red swamp and signal crayfish populations, also becoming more and more frequent, can only be expected in the lower reaches and sparingly, as they usually come into contact in central Spain under $1000 \mathrm{~m}$ a.s.l., since red swamp crayfish is rarely found above this elevation, except in some reservoirs and still waters (Alonso et al., 2000).

\section{CONCLUSIONS}

Twenty-three native crayfish populations were detected within Alto Tajo Natural Park combining different sampling methods. They show a fragmented distribution pattern and a small size common to other Iberian areas. Despite the limitations of our habitat characterisation, crayfish distribution could not be explained in terms of habitat selection, suggesting that stochastic events, mainly drought and plague outbreaks, together with a limited colonisation ability, could have shaped it. Restocking can be regarded as an important management tool, given the success shown here and in similar adjacent areas. The ongoing dispersal of signal crayfish is identified as the main threat for the future of these populations.

\section{ACKNOWLEDGEMENTS}

We greatly thank David Álvarez for his help in the field surveys. Álvaro Antón and Loreto García gave us useful advice on the statistical design. Alto Tajo Natural Park provided funding for this study. 


\section{REFERENCES}

Alonso F., 2004. Population dynamics of crayfish Austropotamobius italicus (Faxon, 1914) in the Iberic Mountains: Applications for the recovery of the species, Ph.D. Dissertation, Universidad Politécnica de Madrid, $278 \mathrm{p}$.

Alonso F., 2010. Austropotamobius pallipes. In: Bases ecológicas preliminares para la conservación de las especies de interés comunitario en España, Invertebrados, Ministerio de Medio Ambiente, y Medio Rural y Marino, Madrid, 71-92.

Alonso F. and Martínez R., 2006. Competition for shelter in laboratory conditions between adult males of two invasive species: signal crayfish (Pacifastacus leniusculus) and red swamp crayfish (Procambarus clarkii). Bull. Fr. Pêche Piscic., 380-381, 1121-1133.

Alonso F., Temiño C. y Diéguez-Uribeondo J., 2000. Status of the white-clawed crayfish, Austropotamobius pallipes (Lereboullet, 1858) in Spain: legislation and conservation. Bull. Fr. Pêche Piscic., 356, 31-54.

Alonso F., Martínez R., Martínez A.L., Lorente E., Valero J.M., Herrera G. and Mora A., 2006. La cría en cautividad del cangrejo de río en Castilla-La Mancha. Quercus, 245, 34-35.

Arce J.A., 2009. Empleo de excrementos de nutria (Lutra lutra) para la diagnosis específica de los cangrejos de río, Actas de las IX Jornadas de la Sociedad Española para la Conservación y Estudio de los Mamíferos, Bilbao.

Benvenuto C., Gherardi F. and Ilhéu M., 2008. Microhabitat use by the white-clawed crayfish in a Tuscan stream. J. Nat. Hist., 42, 21-33.

Bergman D.A. and Moore P.A., 2003. Field observations of intraspecific agonistic behaviour of two crayfish species, Orconectes rusticus and Orconectes virilis, in different habitats. Biol. Bull., 205, 26-35.

Bernardo J.M., Bruxelas S., Bochechas J. and Costa A.M., 2001. Freshwater crayfish in Portugal: a new Astacidae, Pacifastacus leniusculus (Dana), and less perspectives for the rehabilitation of the native Austropotamobius pallipes, Actas do $2^{\circ}$ Congresso Nacional de Conservação da Natureza, Instituto de Conservação da Natureza, Lisboa, 1-6.

Blake M.A. and Hart P.J.B., 1993. Habitat preferences and survival of juvenile signal crayfish, Pacifastacus leniusculus - the influence of water depth, substratum, predatory fish and gravid female crayfish. Freshwater Crayfish, 9, 318-332.

Bubb D.H., Thom T.J. and Lucas M.C., 2005. The within-catchment invasion of the non-indigenous signal crayfish Pacifastacus leniusculus (Dana), in upland rivers. Bull. Fr. Pêche Piscic., 376-377, 665-673.

Clavero D., Benejam L. and Seglar A., 2009. Microhabitat use by foraging white-clawed crayfish (Austropotamobius pallipes) in stream pools in the NE Iberian Peninsula. Ecol. Res., 24, 771-779.

Diéguez-Uribeondo J., 2006. Pathogens, parasites and ectocommensals. In: Souty-Grosset C., Holdich D.M., Noël P., Reynolds J.D. and Haffner P. (eds.), Atlas of Crayfish in Europe, 64, Muséum national d'Histoire naturelle, Paris, 131-149.

Diéguez-Uribeondo J., Rueda A., Castién E. and Bascones J.C., 1997. A plan of restoration in Navarra for the native freshwater crayfish species of Spain, Austropotamobius pallipes. Bull. Fr. Pêche Piscic., 347, 625-637.

Diéguez-Uribeondo J., Royo F., Souty-Grosset C., Ropiquet A. and Grandjean F., 2008. Low genetic variability of the white-clawed crayfish in the Iberian Peninsula: its origin and management implications. Aquat. Conserv., 18, 19-31.

Füreder L., Oberkofler B., Hanel R. and Machino Y., 2002. Freshwater crayfish in South Tyrol (Italy): distribution and protection measures of endangered Austropotamobius pallipes. Bull. Fr. Pêche Piscic., 367, 651-662.

García-Arberas L. and Rallo A., 2000. Survival of natural populations of Austropotamobius pallipes in rivers in Bizkaia, Basque Country (North of Iberian Peninsula). Bull. Fr. Pêche Piscic., 356, 17-30.

Garvey J.E., Stein R.A. and Thomas H.M., 1994. Assessing how fish predation and interspecific prey competition influence a crayfish assemblage. Ecology, 75, 532-547.

Gil J.M., 1999. Situación, biología y conservación del cangrejo de río autóctono (Austropotamobius pallipes) en la provincia de Granada, Ph.D. Dissertation, Universidad de Granada, 211 p.

Gil J.M. and Alba-Tercedor J., 2002. Ecology of the native and introduced crayfishes Austropotamobius pallipes and Procambarus clarkii in southern Spain and implications for conservation of the native species. Biol. Conserv., 105, 75-80. 
Grandjean F., Gouin N., Diéguez-Uribeondo J. and Souty-Grosset C., 2001. Drastic bottlenecks in the endangered crayfish species, Austropotamobius pallipes in Spain with inference to its colonization history. Heredity, 88, 1-8.

Guan R. and Wiles P.R., 1996. Growth, density and biomass of crayfish Pacifastacus leniusculus, in a British lowland river. Aquat. Living Resour., 9, 265-272.

Gydemo R., Westin L. and Nissling A., 1990. Predation on larvae of the noble crayfish Astacus astacus L. Aquaculture, 86, 155-161.

Haffner P., Noël P. and Madec J., 2006. Species files. In: Souty-Grosset C., Holdich D.M., Noël P., Reynolds J.D. and Haffner P. (eds.), Atlas of Crayfish in Europe, 64, Muséum national d'Histoire naturelle, Paris, 49-129.

Holdich D.M. and Domaniewski J.C.J., 1995. Studies on a mixed population of the crayfish Austropotamobius pallipes and Pacifastacus leniusculus in England. Freshwater Crayfish, 10, 37-45.

Jussila J., Henttonen P. and Huner J.V., 1995. Calcium, magnesium and manganese content of the noble crayfish Astacus astacus (L.) branchial carapace and its relationships to water and sediment mineral contents of two ponds and one lake in central Finland. Freshwater Crayfish, 10, 230-238.

Kruuk H., 2006. Otters. Ecology, Behaviour and Conservation, Oxford University Press, Oxford.

Lanzski J. and Sallai S., 2006. Comparison of the feeding habits of Eurasian otters on a fast flowing river and its backwater habitats. Mammalian Biology, 71, 336-346.

Martínez R., Rico E. and Alonso F., 2003. Characterisation of Austropotamobius italicus (Faxon, 1914) populations in a central Spain area. Bull. Fr. Pêche Piscic., 370-371, 43-56.

Mason C.F. and Macdonald S.M., 1986. Otters. Ecology and Conservation, Cambridge University Press, Cambridge, UK.

Munné A., Prat N., Sola C., Bonada N. and Rieradevall M., 2003. A simple field method for assessing the ecological quality of riparian habitat in rivers and streams: QBR index. Aquat. Conserv., 13, 147-163.

Peay S., 2002. A standardised survey and monitoring protocol for the white-clawed crayfish Austropotamobius pallipes in the UK, Life in UK Rivers Project, Contract LIF 02-11-37, English Nature, Peterborough, $58 \mathrm{p}$.

Rallo A. and García-Arberas L., 2000. Population structure and dynamics and habitat conditions of the native crayfish Austropotamobius pallipes in a pond: a case study in Basque Country (Northern Iberian Peninsula). Bull. Fr. Pêche Piscic., 356, 5-16.

Reynolds J., 2002. Growth and reproduction. In: Holdich D.M. (ed.), Biology of Freshwater Crayfish, Blackwell Science, Oxford, 152-191.

Söderback B., 1994. Reproductive interference between two co-occurring crayfish species, Astacus astacus (L.) and Pacifastacus leniusculus (Dana). North. J. Fresh. Res., 69, 137-143.

Sokal R.R. and Rohlf F.J., 1995. Biometry: the principles and practice of statistics in biological research, 3rd edn., W.H. Freeman, New York, 887 p.

Torre M. and Rodríguez P., 1964. El cangrejo de río en España, Servicio Nacional de Pesca Fluvial y Caza, Ministerio de Agricultura, Madrid, $107 \mathrm{p}$.

Troschel H.J. and Dehus P., 1993. Distribution of crayfish species in the Federal Republic of Germany, with special reference to $A$. pallipes. Freshwater Crayfish, 9, 390-398. 